\title{
Substitution of blood plasma with soy protein concentrate in piglet diet
}

\author{
Moisés Queiroz Resende ${ }^{1}$, Alessandra Gimenez Mascarenhas ${ }^{2^{*}}$, Heloisa Helena de Carvalho \\ Mello $^{2}$, Emmanuel Arnhold ${ }^{2}$, Karla Andrade Teixeira ${ }^{3}$, Luciana Moura Rufino ${ }^{1}$, Romão da Cunha \\ Nunes $^{2}$
}

\footnotetext{
${ }^{1}$ Universidade Federal de Goiás, Programa de Pós-graduação em Ciência Animal, Goiânia, GO, Brazil.

${ }^{2}$ Universidade Federal de Goiás, Escola de Veterinária e Zootecnia, Departamento de Zootecnia, Goiânia, GO, Brazil.

${ }^{3}$ Universidade Federal de Goiás, Programa de Pós-graduação em Zootecnia, Goiânia, GO, Brazil.
}

\begin{abstract}
In this study, we evaluated the effects of substitution of partial and total spray-dried blood plasma (BP) with soy protein concentrate (SPC) in the diet of post-weaning piglets on their performance, intestinal histomorphometry, and blood parameters. Fifty-four castrated male piglets, weaned at an average age of 21 days and an initial average weight of $7.01 \pm 0.294 \mathrm{~kg}$, were distributed in a completely randomized block design, with three diets $(0 \% \mathrm{SPC}-5 \% \mathrm{BP}, 2.5 \% \mathrm{SPC}-2.5 \% \mathrm{BP}$, and $5 \% \mathrm{SPC}-0 \% \mathrm{BP}$ ), six replicates, and three piglets per experimental unit. The experimental feeds were formulated to meet the requirements of the piglets at 21-32 and 33-42 days of age (pre-starter diet) and 43-66 days of age (starter diet). From 21 to 32 and 21 to 42 days of age, daily feed intake, daily weight gain, and final weight of the animals were higher in the group fed $2.5 \%$ SPC- $2.5 \%$ BP and $0 \%$ SPC-5\%BP. From 21 to 66 days of age, daily weight gain and daily feed intake were higher in the animals fed $2.5 \% \mathrm{SPC}-2.5 \% \mathrm{BP}$. No effect was observed on the histomorphometry variables. The total leukocyte count was higher in animals fed $2.5 \% \mathrm{SPC}-2.5 \% \mathrm{BP}$ and $5 \% \mathrm{SPC}-0 \% \mathrm{BP}$ and the lymphocyte count was lower in the piglets that received $0 \% \mathrm{SPC}-5 \% \mathrm{BP}$. The combined use of soy protein concentrate and spray-dried blood plasma in the feeds of piglets between 21 and 42 days of age improves their productive performance.
\end{abstract}

Key Words: feed, performance, leukocytes, swine, villus

\section{Introduction}

Early weaning is a critical period in piglets because of the stress associated with the change in diet and environment and the immaturity of the digestive and immune systems. As a result, decreased feed ingestion and rate of weight gain are observed, resulting in reduced post-weaning performance. Changes in the intestinal mucous are also associated with this process, along with predisposition to disease (Pluske et al., 1997).

The plasma produced by "spray dry", known as spraydried plasma (BP), is used widely in post-weaning diets and has demonstrated efficiency in the improvement of piglet performance during this period. Spray-dried plasma is

Received: August 9, 2016

Accepted: January 10, 2017

*Corresponding author: alegimenez09@hotmail.com

http://dx.doi.org/10.1590/S1806-92902017000400008

How to cite: Resende, M. Q.; Mascarenhas, A. G.; Mello, H. H. C.; Arnhold, E.; Teixeira, K. A.; Rufino, L. M. and Nunes, R. C. 2017. Substitution of blood plasma with soy protein concentrate in piglet diet. Revista Brasileira de Zootecnia 46(4):324-330.

Copyright (C) 2017 Sociedade Brasileira de Zootecnia. This is an Open Access article distributed under the terms of the Creative Commons Attribution License (http://creativecommons.org/licenses/by/4.0/), which permits unrestricted use, distribution, and reproduction in any medium, provided the original work is properly cited. considered a high-quality supplement of pleasant taste and is an alternative method to stimulate increased absorption of nutrients and the intake of young animals (Bikker et al., 2004). According to Torrallardona, (2010), its use improves the feed intake and weight gain in piglets compared with other protein sources, whether of animal or vegetable origin.

The palatability of blood plasma is responsible for the initial increase in feed intake and, consequently, an improvement in post-weaning weight gain (Ermer et al., 1994). In addition, other mechanisms responsible for the improved performance of piglets have been suggested. For example, according to Bosi et al. (2004), blood plasma is responsible for maintaining the integrity of the intestinal mucous and for reducing the inflammatory response in the intestine, which assists the piglets to overcome sanitary challenges. It has been suggested that plasma decreases the adherence and proliferation of pathogens in the intestinal mucous, which decreases the stimulation of the local and systemic immune systems, resulting in increased nutrient availability for growth (Campbell et al., 2008).

The use of spray-dried plasma in feeds is beneficial, mainly in terms of the performance of post-weaning piglets; however, its price is high (Pettigrew, 2006). Soy protein concentrate (SPC), which does not contain antinutritional 
factors, such as allergenic proteins and oligosaccharides that are present in soybean meal, is effective in improving the performance of post-weaning piglets (Lenehan et al., 2007; Yang et al., 2007).

Thus, the present study sought to assess the effects of substitution of spray-dried plasma with soy protein concentrate in the diet of weaned piglets at 21 days of age on performance, intestinal histomorphometry, and some blood parameters.

\section{Material and Methods}

The experiment was conducted in Goiânia, Brazil. The project was submitted for evaluation to the Ethics Committee on the Use of Animals (CEUA) and approved under case number 062/12.

Fifty-four barrows, weaned at 21 days of age, were housed in suspended cages located in a nursery shed. The cages had a perforated plastic floor, with nipple water fountains, shell and PVC gutter feeders with four holes, and a linear area of $0.90 \mathrm{~m}$. The cages were equipped with
$100-\mathrm{W}$ incandescent lamps for heating. Temperature and humidity were monitored daily using a thermometer and a hygrometer installed in an empty cage in the center of the room, at the same height as the animals.

The piglets were evaluated for umbilical and scrotum healing, hydration, and behavior. Then, they were weighed and distributed in pens with animals of uniform weight.

The experimental design was completely randomized blocks, with three treatments, six replicates, and three animals per experimental unit, for a total of 18 experimental units. The criteria adopted to form the blocks were the body weight of piglets at weaning. The pen was considered an experimental unit.

Water and feed were provided ad libitum for the piglets during the whole experimental period, which lasted 45 days (21 to 66 days of age).

The pre-starter diets provided from 21 to 32 and from 33 to 42 days of age contained 0.0/5.0,2.5/2.5, and 5.0/0.0\% SPC/BP (Table 1). From 43 to 66 days of age, all piglets received the same starter diet, based on corn-soybean meal, to evaluate the residual effect of the treatments applied in

Table 1 - Nutritional and centesimal composition of experimental diets offered to piglets from 21 to 32 and of 32 to 42 days of age

\begin{tabular}{|c|c|c|c|c|c|c|}
\hline \multirow{3}{*}{ Item } & \multicolumn{3}{|c|}{21 to 32 days } & \multicolumn{3}{|c|}{32 to 42 days } \\
\hline & \multicolumn{3}{|c|}{$\mathrm{SPC} / \mathrm{BP}(\%)$} & \multicolumn{3}{|c|}{$\mathrm{SPC} / \mathrm{BP}(\%)$} \\
\hline & $0 / 5$ & $2.5 / 2.5$ & $5 / 0$ & $0 / 5$ & $2.5 / 2.5$ & $5 / 0$ \\
\hline \multicolumn{7}{|l|}{ Ingredient (kg/100 kg) } \\
\hline Corn & 56.133 & 54.846 & 53.529 & 53.480 & 52.091 & 50.786 \\
\hline Soybean meal $45 \%$ & 20.643 & 21.795 & 23.124 & 24.249 & 25.510 & 26.756 \\
\hline Dried whey & 10.000 & 10.000 & 10.000 & 10.000 & 10.000 & 10.000 \\
\hline Soy protein concentrate & 0.000 & 2.500 & 5.000 & 0.000 & 2.500 & 5.000 \\
\hline Blood plasma & 5.000 & 2.500 & 0.000 & 5.000 & 2.500 & 0.000 \\
\hline Soybean oil & 3.615 & 3.834 & 4.000 & 3.486 & 3.707 & 3.900 \\
\hline Dicalcium phosphate & 1.985 & 2.005 & 2.024 & 1.678 & 1.697 & 1.717 \\
\hline Limestone & 0.513 & 0.485 & 0.457 & 0.619 & 0.591 & 0.563 \\
\hline L-lysine HCL & 0.950 & 0.793 & 0.634 & 0.683 & 0.523 & 0.363 \\
\hline DL-methionine & 0.113 & 0.089 & 0.064 & 0.066 & 0.041 & 0.017 \\
\hline L-threonine & 0.441 & 0.362 & 0.279 & 0.305 & 0.224 & 0.142 \\
\hline L-tryptophan & 0.107 & 0.142 & 0.093 & 0.062 & 0.055 & 0.048 \\
\hline Vitamin premix ${ }^{1}$ & 0.300 & 0.300 & 0.300 & 0.300 & 0.300 & 0.300 \\
\hline Mineral premix ${ }^{2}$ & 0.050 & 0.050 & 0.050 & 0.050 & 0.050 & 0.050 \\
\hline Salt & 0.145 & 0.293 & 0.441 & 0.018 & 0.207 & 0.355 \\
\hline Total & 100 & 100 & 100 & 100 & 100 & 100 \\
\hline \multicolumn{7}{|l|}{ Calculated values ${ }^{3}$} \\
\hline Metabolizable energy (kcal/kg) & 3.375 & 3.375 & 3.375 & 3.375 & 3.375 & 3.375 \\
\hline Crude protein $(\%)$ & 20.00 & 20.00 & 20.00 & 21.00 & 21.00 & 21.00 \\
\hline Digestible lysine (\%) & 1.450 & 1.450 & 1.450 & 1.330 & 1.330 & 1.330 \\
\hline Digestible methionine (\%) & 0.406 & 0.406 & 0.406 & 0.372 & 0.372 & 0.372 \\
\hline Digestible threonine $(\%)$ & 0.914 & 0.914 & 0.914 & 0.838 & 0.838 & 0.838 \\
\hline Digestible tryptophan $(\%)$ & 0.261 & 0.261 & 0.261 & 0.239 & 0.239 & 0.239 \\
\hline Calcium $(\%)$ & 0.850 & 0.850 & 0.850 & 0.825 & 0.825 & 0.825 \\
\hline Available phosphorous (\%) & 0.500 & 0.500 & 0.500 & 0.450 & 0.450 & 0.450 \\
\hline Sodium $(\%)$ & 0.280 & 0.280 & 0.280 & 0.230 & 0.246 & 0.246 \\
\hline
\end{tabular}

$\mathrm{SPC} / \mathrm{BP}(\%)$ - amounts of soy protein concentrate e amount of blood plasma in diets.

${ }^{1}$ Amount per kg of diet: $0.25 \mathrm{mg}$ folic acid; $9.33 \mathrm{mg}$ pantothenic acid; $7.98 \mathrm{mg} \mathrm{Cu} ; 0.05 \mathrm{~g}$ Fe; $0.30 \mathrm{mg} \mathrm{I} ; 14.90 \mathrm{mg} \mathrm{Mn} ; 15.99 \mathrm{mg}$ niacin; $0.36 \mathrm{mg}$ Se; $22.00 \mathrm{mg}$ tylosin; $3.19 \mathrm{IU}$ vitamin A; $0.50 \mathrm{mg}$ vitamin B1; $10.49 \mu \mathrm{g}$ vitamin B12; $2.80 \mathrm{mg}$ vitamin B2; $0.60 \mathrm{mg}$ vitamin B6; $649 \mathrm{IU}$ vitamin D3; $8.49 \mathrm{IU}$ vitamin E; $0.99 \mathrm{mg}$ vitamin K3; $0.08 \mathrm{~g}$ Zn.

${ }^{2}$ Amount per kg of diet: $0.05 \mathrm{~g} \mathrm{Cu} ; 0.29 \mathrm{~g} \mathrm{Fe} ; 1.80 \mathrm{mg} \mathrm{I} ; 0.08 \mathrm{~g} \mathrm{Mn} ; 0.48 \mathrm{~g} \mathrm{Zn}$.

${ }^{3}$ According to Rostagno et al (2011). 
the pre-starter phase (Table 2). The diets conformed to the nutritional requirements for each stage as recommended by Rostagno et al. (2011).

A commercial source of soy protein concentrate containing $60 \%$ crude protein, $5 \%$ fiber, $5 \%$ mineral matter, $2 \%$ crude fat, $10 \%$ moisture, $18 \%$ nitrogen free extract, and $3 \mathrm{mg} / \mathrm{g}$ trypsin inhibitor activity was used.

To evaluate the performance, the piglets were weighed at 21,32 , and 43 days of age and at the end of the experimental period (66 days of age). Feed waste was collected daily and weighed at the end of each period, when piglets were 32, 42 , and 66 days of age, to determine daily feed intake, daily weight gain, and feed conversion. The performance data were analyzed independently for each evaluation period at 21 to 32,21 to 42 , and 21 to 66 days of age.

Blood was collected at 32 days of age $(5 \mathrm{~mL})$ from 18 animals (one per experimental unit) via puncture of the jugular vein. The blood was transferred to a tube containing ethylenediaminetetraacetic acid anticoagulant and then homogenized and stored in a cooler box with recyclable ice until analysis. Total erythrocyte, platelet, and leukocyte counts were obtained using a compact automatic

Table 2 - Nutritional and centesimal composition of experimental feeds offered to piglets from 43 to 66 days of age

\begin{tabular}{|c|c|}
\hline & Experimental diet \\
\hline \multicolumn{2}{|l|}{ Ingredient $(\mathrm{kg} / 100 \mathrm{~kg})$} \\
\hline Corn & 68.614 \\
\hline Soybean meal 45\% & 27.170 \\
\hline Soybean oil & 0.949 \\
\hline Dicalcium phosphate & 1.386 \\
\hline Limestone & 0.733 \\
\hline L-lysine HCL & 0.299 \\
\hline DL-methionine & 0.019 \\
\hline L-threonine & 0.070 \\
\hline Vitamin premix $^{1}$ & 0.300 \\
\hline Mineral premix ${ }^{2}$ & 0.050 \\
\hline Salt & 0.405 \\
\hline Total & 100 \\
\hline \multicolumn{2}{|l|}{ Calculated values $^{3}$} \\
\hline Metabolizable energy $(\mathrm{kcal} / \mathrm{kg})$ & 3.230 \\
\hline Crude protein $(\%)$ & 18.13 \\
\hline Digestible lysine (\%) & 1.037 \\
\hline Digestible methionine (\%) & 0.290 \\
\hline Digestible threonine (\%) & 0.653 \\
\hline Digestible tryptophan (\%) & 0.190 \\
\hline Calcium $(\%)$ & 0.733 \\
\hline Available phosphorous (\%) & 0.360 \\
\hline Sodium $(\%)$ & 0.200 \\
\hline \multicolumn{2}{|c|}{$\begin{array}{l}{ }^{1} \text { Content per kg of product: } 83.33 \mathrm{mg} \text { folic acid; } 3111.04 \mathrm{mg} \text { pantothenic acid; } \\
2660.88 \mathrm{mg} \text { copper; } 17.96 \mathrm{~g} \text { iron; } 100.03 \mathrm{mg} \text { iodine; } 4977.91 \mathrm{mg} \text { manganese; } \\
5333.12 \mathrm{mg} \text { niacin; } 120.00 \mathrm{mg} \text { selenium; } 7333.34 \mathrm{mg} \text { tylosin; } 1066.624 \mathrm{IU} \text { vitamin } \mathrm{A} \text {; } \\
166.66 \mathrm{mg} \text { vitamin B1; } 3499.86 \mu \mathrm{g} \text { vitamin B12; } 933.30 \mathrm{mg} \text { vitamin B2; } 199.99 \mathrm{mg} \\
\text { vitamin B6; } 216.650 \mathrm{IU} \text { vitamin D3; } 2833 \mathrm{IU} \text { vitamin E; } 333.32 \mathrm{mg} \text { vitamin K3; } \\
26.67 \mathrm{~g} \text { zinc. } \\
{ }^{2} \text { Content per kg of product: } 15.97 \mathrm{~g} \text { copper; } 99.00 \mathrm{~g} \text { iron; } 600.16 \mathrm{mg} \text { iodine; } 29.87 \mathrm{~g} \\
\text { manganese; } 160.00 \mathrm{~g} \text { zinc. } \\
{ }^{3} \text { According to Rostagno et al. (2011). }\end{array}$} \\
\hline
\end{tabular}

hematology analyzer $\left(\right.$ Mindray $^{\circledR}$ equipment model BC 2800 VET).

For the differential leukocyte counts, a blood film was prepared for each sample. In a small beaker, 100 drops of Giempa $\left(\right.$ Doles $^{\circledR}$ ) were diluted in $100 \mathrm{~mL}$ distilled water. This solution was distributed across the slides to stain them. After $25 \mathrm{~min}$, the slides were washed under running water and air-dried. After preparation, the blood films were placed under a light microscope at 1000X magnification (optical of $100 \mathrm{X})$ and 100 leukocytes were counted, 50 in the inferior border and 50 in the superior border of the film. The absolute values were obtained by multiplying the relative value by the total number of leukocytes in the sample.

After blood collection, the 18 piglets were euthanized in accordance with the principles of animal welfare and humanitarian slaughter to minimize any stress during the procedure. The piglets were desensitized by electronarcosis, followed by bloodletting through incision of the blood vessels in the neck.

To evaluate the histomorphometry, three intestinal segments, each approximately $2.0 \mathrm{~cm}$ long, were collected from the duodenum (at $20 \mathrm{~cm}$ from the pylorus), from the jejunum (from the median portion of the small intestine), and from the ileum (at $20 \mathrm{~cm}$ from the ileocecal junction). After collection, the mesenteric border was opened and fixed in a $10 \%$ formalin solution, tamponed in $\mathrm{pH} 7.2$ for $24 \mathrm{~h}$. After fixation, samples were transferred to a histological cassette and stored in $70 \%$ alcohol until processing.

In the laboratory, samples were soaked for $1 \mathrm{~h}$ in increasing concentrations of alcohol $(70 \%, 85 \%, 95 \%$, and absolute PA). The cassettes were then placed in three solutions of xylol for $30 \mathrm{~min}$ each, followed by three soakings in liquid paraffin before being embedded in a block of paraffin wax. The blocks were then frozen before being sectioned by a microtome at an approximate thickness of $5 \mu \mathrm{m}$, semi-seriated with a minimum interval of $50 \mu \mathrm{m}$.

The slides were stained with hematoxylin and eosin (Luna, 1968) and evaluated under a light microscope (Leica DM2500) with 50X magnification (objective of 5X) and images were captured. From the images, 25 intact villi were measured in each segment with the help of ImageJ software and its respective crypts, well oriented and sectioned longitudinally.

Performance, mucosa, and blood data were subjected to analysis of variance (ANOVA) and means were compared using Tukey's test at $5 \%$ probability. The statistical analyses were performed using software R (R Development Core Team, 2011). 


\section{Results and Discussion}

The average minimum and maximum temperatures registered during the experiment were 21.2 and $33.8^{\circ} \mathrm{C}$, respectively.

Between 21 and 32 days of age (Table 3), daily weight gain improved $(\mathrm{P}=0.031)$ with the use of 0 and $2.5 \%$ SPC in the diets. When 5\% SPC was added to the diets to substitute plasma, the piglets exhibited reduced weight gain. The use of $2.5 \%$ SPC associated with $2.5 \%$ plasma resulted in a higher daily feed intake $(\mathrm{P}=0.004)$. The final weight of piglets in this period was also statistically different $(\mathrm{P}=0.025)$, with higher weight at 32 days of age with the use of $2.5 \%$ SPC. There was no significant difference $(\mathrm{P}=0.287)$ between the feed:gain ratio of the fed piglets with different levels of soy protein concentrate in the diets. Similar results were obtained by Pierce et al. (2005), with piglets between 21 and 28 days of age, when compared with a diet containing $10 \%$ SPC and another with $8 \%$ BP. These authors observed higher weight gain and feed intake in piglets fed diets containing plasma, with no difference in feed:gain ratio. The results obtained by Abreu et al. (2010) are consistent with those obtained in the present study. These authors observed that the presence of 2 or $4 \%$ BP promoted increased feed intake and weight gain, with no difference observed in the feed conversion of piglets between 21 and 35 days of age. These results are

Table 3 - Effect of different amounts of soy protein concentrate (SPC) and spray-dried blood plasma (BP) in diets on performance of piglets in the periods of 21-32, 21-42, and 21-66 days of age

\begin{tabular}{|c|c|c|c|c|c|}
\hline \multirow{2}{*}{ Variable } & \multicolumn{3}{|c|}{$\mathrm{SPC} / \mathrm{BP}(\%)$} & \multirow{2}{*}{ P-value } & \multirow{2}{*}{ CV (\%) } \\
\hline & $0 / 5$ & $2.5 / 2.5$ & $5 / 0$ & & \\
\hline \multicolumn{6}{|c|}{21 to 32 days of age } \\
\hline Initial weight $(\mathrm{kg})$ & 7.343 & 7.334 & 7.295 & 0.434 & 0.89 \\
\hline Final weight $(\mathrm{kg})$ & $9.235 \mathrm{ab}$ & $9.673 \mathrm{a}$ & $8.649 b$ & 0.025 & 5.36 \\
\hline Weight gain $(\mathrm{kg} / \mathrm{d})$ & $0.173 \mathrm{ab}$ & $0.213 \mathrm{a}$ & $0.125 b$ & 0.031 & 25.02 \\
\hline Feed intake $(\mathrm{kg} / \mathrm{d})$ & $0.268 \mathrm{~b}$ & $0.325 \mathrm{a}$ & $0.253 b$ & 0.004 & 8.49 \\
\hline Feed:gain (g/g) & 1.626 & 1.645 & 2.032 & 0.287 & 19.11 \\
\hline \multicolumn{6}{|c|}{21 to 42 days of age } \\
\hline Initial weight $(\mathrm{kg})$ & 7.343 & 7.334 & 7.295 & 0.434 & 0.89 \\
\hline Final weight (kg) & $14.682 \mathrm{ab}$ & $15.436 \mathrm{a}$ & $13.231 b$ & 0.013 & 6.22 \\
\hline Weight gain (kg/d) & $0.377 \mathrm{a}$ & $0.406 \mathrm{a}$ & $0.281 b$ & 0.004 & 11.95 \\
\hline Feed intake (kg/d) & $0.471 \mathrm{ab}$ & $0.533 \mathrm{a}$ & $0.411 b$ & 0.001 & 7.19 \\
\hline Feed:gain (g/g) & $1.235 b$ & $1.317 \mathrm{ab}$ & $1.475 \mathrm{a}$ & 0.026 & 7.29 \\
\hline \multicolumn{6}{|c|}{21 to 66 days of age } \\
\hline Initial weight (kg) & 7.343 & 7.334 & 7.295 & 0.434 & 0.89 \\
\hline Final weight (kg) & 31.164 & 32.951 & 31.99 & 0.367 & 5.64 \\
\hline Weight gain $(\mathrm{kg} / \mathrm{d})$ & $0.541 \mathrm{ab}$ & $0.573 \mathrm{a}$ & $0.507 b$ & 0.026 & 5.49 \\
\hline Feed intake (kg/d) & $0.888 \mathrm{ab}$ & $0.944 a$ & $0.85 b$ & 0.044 & 5.55 \\
\hline Feed:gain (g/g) & 1.641 & 1.648 & 1.679 & 0.735 & 3.98 \\
\hline
\end{tabular}

$\mathrm{CV}$ - coefficient of variation.

Averages followed by different letters on the row differ among themselves by the Tukey test $(\mathrm{P}<0.05)$. consistent with those reported by Hu et al. (2014), such that diets containing both soy protein concentrate and plasma had a greater beneficial effect on daily weight gain and average daily intake during the first post-weaning week.

Ermer et al. (1994) and Van Dijk et al. (2001) suggested that the optimal performance during this period is related to the increased palatability of the feed with the inclusion of plasma and its health-promoting effects. However, in the present study, the use of feed with $2.5 \%$ SPC and $2.5 \%$ SPC promoted higher feed intake than that with $5 \%$ BP; yet, no significant difference in weight gain was observed. Thus, the synergistic effect of these two feeds was observed only on feed intake, while the use of plasma at $5 \%$, as well as $2.5 \%$ level, had no effect on weight gain. This can be explained by the increased palatability of feed and the decreased stimulation of the immune system in animals fed plasma.

From 21 to 42 days of age, the complete substitution of plasma with soy protein concentrate was unfavorable for piglet performance (Table 3), but the association of the two supplements was positive. Daily weight gain increased $(\mathrm{P}=0.004)$ with the use of $5 \%$ and $2.5 \% \mathrm{BP}$ associated with $2.5 \%$ SPC compared with the use of $5 \%$ SPC. Higher daily feed intake $(P=0.001)$ and higher weight of the piglets at 42 days of age $(\mathrm{P}=0.013)$ occurred with the utilization of $2.5 \%$ SPC. The feed:gain ratio was lower $(\mathrm{P}=0.026)$ with the inclusion of $5 \% \mathrm{BP}$ compared with the inclusion of $5 \%$ SPC. These results corroborate those reported by Abreu et al. (2010) in the same evaluation period. Conversely, Hernandez et al. (2010) showed that the most marked effect of plasma is observed in the first week following weaning and, from the second week, this effect is not observed.

The difference in the live weight of piglets at 42 days of age was $2.205 \mathrm{~kg}$ between those fed the diet containing $2.5 \%$ SPC with $2.5 \% \mathrm{BP}$ and those fed the diet with $5 \%$ SPC. This difference was due to the performance variables, which demonstrates synergy between plasma and soy protein concentrate. These results are consistent with those reported by $\mathrm{Hu}$ et al. (2014), who obtained higher final weight in the animals receiving a diet containing both soy protein concentrate and plasma. According to Coffey and Cromwell (1995), the best performance results are obtained with the use of plasma when the swine are raised in environments with a high pathogenic load. This result, together with the high digestibility of the soy protein concentrate and the high palatability of the plasma, may explain the results obtained in the present study. Although the experimental shed was disinfected at the beginning of the experiment, during the first 21 days, the floor under the cages was 
cleaned every two days; but the floor was not washed using water to avoid more stress in the animals. Therefore, increased contamination of the environment throughout the experiment may have influenced performance in response to diets containing plasma.

In relation to the total period of the experiment (Table 3), from 21 to 66 days of age, the utilization of $2.5 \%$ SPC promoted higher daily weight gain $(\mathrm{P}=0.026)$ and daily feed intake $(\mathrm{P}=0.044)$. However, utilization of soy protein concentrate in the diets had no effect on the feed:gain ratio $(\mathrm{P}=0.735)$ or the final weight of the animals at 66 days of age $(\mathrm{P}=0.367)$. Between 43 and 66 days of age, all the animals were fed a single feed. Thus, it is possible to infer that there was a residual effect of plasma following its removal from the diet based on the results observed for weight gain and feed intake, an effect that was not observed by Formigoni (2012).

The weight of piglets at the end of the pre-starter phase (42 days of age) may have been involved in performance maintenance once a single initial feed was supplied. When evaluating the levels of plasma in the feed of weaned piglets at 21 days of age, Barbosa et al. (2007) observed that after being supplied with a single diet without plasma in the initial phase (43 to 56 days of age), the animals that presented the best final weight at 42 days of age and had received a feed with $2 \%$ BP between 36 and 42 days of age also presented the best final weight at 56 days of age. This demonstrated the tendency of the animals with better post weaning performance, influenced by the intake of plasma, maintaining themselves heavier after the removal of this supplement from the feed.

Soy protein concentrate, which is a product obtained from soybean and known for the absence of allergenic proteins (Glycinine and B-conglycinine) (Leneham et al., 2007) and oligosaccharides (Dersjant-Li and Peisker, 2010), resulted in the worst performance results in the three periods analyzed, with $100 \%$ substitution of sray-dried plasma with soy protein concentrate in the diet of piglets. However, the substitution of $50 \%$ BP with soy protein concentrate showed the best performance results in all periods studied. It is suggested, therefore, that the association of these two supplements in post weaning diets exerts a positive influence on the performance of the piglets.

In the intestinal histomorphometry (Table 4), no influence of the treatments was found on the variables studied. The results obtained by Abreu et al. (2010), in relation to the presence of plasma in the diets, were similar to those found in the present study, although the material used for this analysis was collected from 42-day-old piglets. Conversely, Yi et al. (2005) affirmed that the performance of the piglets following intake of plasma can be explained, in part, by the capacity of this supplement to avoid intense retraction in the height of the villus, even when challenged with pathogenic bacteria, after the weaning process. This improves the digestion process in level of intestinal mucous and increases the surface area of this mucous, increasing the absorption of the nutrients.

At 32 days of age, blood samples were collected for analysis; the substitution of plasma with soy protein concentrate (Table 5) showed no effect on the relative lymphocyte $(\mathrm{P}=0.276)$ and eosinophil $(\mathrm{P}=0.353)$ counts, or on the absolute eosinophil counts $(\mathrm{P}=0.225)$. In relation to the blood leukocyte $(\mathrm{P}=0.043)$ and lymphocyte $(\mathrm{P}=0.024)$ count, significant differences were observed between the diets; the presence of 5\% BP in the diet led to lower values of leukocyte and lymphocyte count compared to $5 \%$ of SPC. As described by Meyer and Harvey (2004), the cell counts in the present study are within standard counts for swine. Furthermore, plasma can relieve the activation of the lymphatic tissue system associated with

Table 4 - Effect of different amounts of soy protein concentrate (SPC) e spray-dried blood plasma (BP) in diets on intestinal histomorphometry of piglets at 32 days of age

\begin{tabular}{|c|c|c|c|c|c|}
\hline \multirow{2}{*}{ Variable } & \multicolumn{3}{|c|}{$\mathrm{SPC} / \mathrm{BP}(\%)$} & \multirow{2}{*}{ P-value } & \multirow{2}{*}{$\mathrm{CV}(\%)$} \\
\hline & $0 / 5$ & $2.5 / 2.5$ & $5 / 0$ & & \\
\hline \multicolumn{6}{|c|}{ Duodenum } \\
\hline Villus height ( $\mu \mathrm{m})$ & 317 & 295 & 292 & 0.738 & 18.97 \\
\hline Crypt depth $(\mu \mathrm{m})$ & 445 & 474 & 444 & 0.621 & 11.99 \\
\hline Villus height:crypt depth & 0.713 & 0.634 & 0.659 & 0.626 & 21.96 \\
\hline \multicolumn{6}{|c|}{ Jejunum } \\
\hline Villus height $(\mu \mathrm{m})$ & 276 & 261 & 279 & 0.813 & 19.73 \\
\hline Crypt depth $(\mu \mathrm{m})$ & 289 & 326 & 321 & 0.298 & 12.59 \\
\hline Villus height:crypt depth & 0.962 & 0.823 & 0.867 & 0.374 & 19.98 \\
\hline \multicolumn{6}{|c|}{ Ileum } \\
\hline Villus height $(\mu \mathrm{m})$ & 277 & 302 & 316 & 0.421 & 17.72 \\
\hline Crypt depth $(\mu \mathrm{m})$ & 255 & 246 & 269 & 0.375 & 11.15 \\
\hline Villus height:crypt depth & 1.095 & 1.24 & 1.178 & 0.392 & 15.79 \\
\hline
\end{tabular}

Table 5 - Effect of different amounts of soy protein concentrate (SPC) e spray-dried blood plasma (BP) in diets on blood cells of piglets at 32 days of age

\begin{tabular}{lccccc}
\hline \multirow{2}{*}{ Variable } & \multicolumn{4}{c}{ SPC/BP (\%) } & \\
\cline { 2 - 5 } & $0 / 5$ & $2.5 / 2.5$ & $5 / 0$ & P-value & CV (\%) \\
\hline Leukocytes $\left(\times 10^{3} / \mathrm{mm}^{3}\right)$ & $13.502 \mathrm{~b}$ & $15.35 \mathrm{ab}$ & $19.639 \mathrm{a}$ & 0.043 & 18.17 \\
Lymphocytes $\left(\times 10^{3} / \mathrm{mm}^{3}\right)$ & $6.214 \mathrm{~b}$ & $9.25 \mathrm{a}$ & $9.815 \mathrm{a}$ & 0.024 & 18.03 \\
Lymphocytes $(\%)$ & 52.02 & 59.89 & 50.65 & 0.276 & 17.6 \\
Eosinophils $\left(\times 10^{3} / \mathrm{mm}^{3}\right)$ & 379 & 258 & 438 & 0.225 & 45.29 \\
Eosinophils $(\%)$ & 2.14 & 1.47 & 2.19 & 0.353 & 39.05 \\
\hline
\end{tabular}

$\mathrm{CV}$ - coefficient of variation.

Averages followed by different letters on the row differ among themselves by the Tukey test $(\mathrm{P}<0.05)$. 
the intestine and cells from the systemic immune system, allowing more energy for growth (Demas et al., 1997; Perez-Bosque et al., 2004).

The weaning process, along with its challenges and changes, is associated with a greater activation of the immune system in piglets, which is generally associated with intestinal inflammation and a systemic proinflammatory response with increased production of defense cells and cytokines (Moretó and Pérez-Bosque, 2009). These changes are associated with the diversion of nutrients required for animal growth for use in the immune response, resulting in a reduction in weight gain. Nevertheless, Jiang et al. (2000) observed that addition of spray-dried plasma in the diet of post-weaning piglets increased their efficiency in utilizing the dietary protein, consequently improving the performance of piglets. These results are consistent with the results of the present study and may be explained by the results of the study by Nofrarías et al. (2006), who demonstrated that spray-dried plasma reduces immune system stimulation, which decreases the production of defense cells, thereby increasing the availability of nutrients for tissue deposition.

The leukocyte count was lowest in the diet with $100 \%$ substitution of spray-dried plasma with soy protein concentrate, which highlights the effect of plasma described by Nofrarías et al. (2006). Nevertheless, despite the positive influence of spray-dried plasma on piglet performance in the present study, the diet containing 5\% BP did not lead to the best performance; however, the diet containing $2.5 \%$ $\mathrm{BP}$ and $2.5 \%$ SPC led to the best performance. This can be explained by the reduced stimulation of the immune system caused by the presence of spray-dried plasma and by the protein quality of the soy protein concentrate, together with its high digestibility, as described by Yang et al. (2007).

\section{Conclusions}

The combined use of soy protein concentrate and spray-dried blood plasma in the feeds of piglets between 21 and 42 days of age improves their performance.

\section{Acknowledgments}

We thank the company Sementes Selecta S/A for the support in the execution of this work.

\section{References}

Abreu, M. L. T.; Donzele, J. L.; Saraiva, A.; Oliveira, R. F. M.; Fortes, E. I. and Graña, G. L. 2010. Glutamina, nucleotídeos e plasma suíno em rações para leitões desmamados. Revista Brasileira de Zootecnia 39:520-525.

Barbosa F. F.; Ferreira A. S.; Gattás G.; Silva, F. C. O.; Donzele, J. L.; Brustolini, P. C. and Lopes, D. C. 2007. Níveis de plasma sanguíneo em pó em dietas para leitões desmamados aos 21 dias de idade. Revista Brasileira de Zootecnia 36:1052-1060.

Bikker, P.; Van Dijk, A. J.; Dirkzwager, A.; Fledderus, J.; UbbinkBlanksma, M.; Beynen, A. C. 2004. The influence of diet composition and an anti-microbial growth promoter on the growth response of weaned piglets to spray dried animal plasma. Livestock Science 86:201-208.

Bosi, P.; Casini, L.; Finamore, A.; Cremokolini, C.; Merialdi, G.; Trevisi, P.; Nobili, F. and Mengheri, E. 2004. Spray-dried plasma improves growth performance and reduces inflammatory status of weaned pigs challenged with enterotoxigenic Escherichia coli K88. Journal of Animal Science 2:1764-1772.

Campbell, J.; Crewshaw, J.; Russell, L.; Hayes, S.; Barancelli, G. V. and Rangel, L. F. S. 2008. Uso do plasma para modular a resposta inflamatória e o seu impacto na produção de suínos. Acta Scientiae Veterinariae 36:s53-s59.

Coffey, R. D. and Cromwell, G. L. 1995. The impact of environment and antimicrobial agents on the growth response of early-weaned pigs to spray-dried porcine plasma. Journal of Animal Science $73: 2532-2539$.

Demas, G. E.; Chefer, V.; Talan, M. I. and Nelson, R. J. 1997. Metabolic costs of mounting an antigen stimulated immune response in adult and aged $\mathrm{C} 57 \mathrm{BL} / 6 \mathrm{~J}$ mice. American Journal Physiology 273:1631-1637.

Dersjant-Li, Y. and Peisker, M. 2010. The impact of soy oligosaccharides on digestion and intestinal health in weaning piglets. Livestock Science 134:187-189.

Ermer, P. M.; Miller, P. S. and Lewis, A. J. 1994. Diet preference and meal patterns of weanling pigs offered diets containing either spray-dried porcine plasma or dried skim milk. Journal of Animal Science 72:1548-1554.

Formigoni, A. S. 2012. Níveis de plasma sanguíneo em dietas com antibiótico para leitões desmamados aos 21 dias de idade. Dissertação (M. Sc.). Universidade Federal de Viçosa, Viçosa, MG, Brasil.

Hernández, A.; Hansena, C. F.; Mansfielda, J.; Mullanb, B. P. and Pluske, J. R. 2010. The responses of light- and heavy-for-age pigs at weaning to dietary spray-dried porcine plasma. Animal Feed Science and Technology 162:116-122.

Hu, L.; Che, L.; Luo, G.; Su, G.; Fei, H.; Xuan, Y.; Fang, Z.; Lin, Y.; Xu, S.; Yang, W.; Wu, Z. and Wu, D. 2014. Effects of yeastderived protein $v s$ spray-dried porcine plasma supplementation on growth performance, metabolism and immune response of weanling piglets. Italian Journal of Animal Science 13:163-168.

Jiang, R.; Chang, X.; Stoll, B.; Ellis, K. J.; Shypailo, R. J.; Weaver, E.; Campbell, J. and Burrin, D. G. 2000. Dietary plasma protein is used more efficiently than extruded soy protein for lean tissue growth in early-weaned pigs. Journal of Nutrition 130:2016-2019.

Lenehan, N. A.; Derouchey, J. M.; Goodband, R. D.; Tokach, M. D.; Dritz, S. S.; Nelssen, J. L.; Groesbeck, C. N. and Lawrence, K. R. 2007. Evaluation of soy protein concentrates in nursery pig diets. Journal of Animal Science 85:3013-3021.

Luna, L. G. 1968. Manual of the histologic staining methods of the armed forces institute of pathology. 3rd ed. New York, McGraw Hill.

Meyer, D. J. and Harvey, J. W. 2004. Veterinary laboratory medicine: interpretation \& diagnosis. 2nd ed. Sauders, Philadelphia.

Moretó, M. and Perez-Bosque, A. 2009. Dietary plasma proteins, the intestinal immune system, and the barrier functions of the intestinal mucosa. Journal of Animal Science 87(E. Suppl.):E92-E100. 
Nofrarías, M.; Manzanilla, E. G.; Pujols, J.; Gibert, X.; Majo, N.; Segales, J. and Gasa, J. 2006. Effects of spray-dried porcine plasma and plant extracts on intestinal morphology and on leukocyte cell subsets of weaned pigs. Journal of Animal Science 84:2735-2742.

Perez-Bosque, A.; Pelegri, C.; Vicario, M.; Castell, M.; Russell, L.; Campbell, J. M.; Quigley, J. D. III; Polo, J.; Amat, C. and Moreto, M. 2004. Dietary plasma protein affects the immune response of weaned rats challenged with S. aureus Superantigen. British Journal of Nutrition 134:2667-2672.

Pettigrew, J. E. 2006. Reduced use of antibiotic growth promoters in diets fed to weanling pigs: dietary tools, part 1. Animal Biotechnology 17:207-215.

Pierce, J. L.; Cromwell, G. L.; Lindemann, M. D.; Russell, L. E. and Weaver, E. M. 2005. Effects of spray-dried animal plasma and immunoglobulins on performance of early weaned pigs. Journal of Animal Science 83:2876-2885.

Pluske, J. R.; Hampson, D. J. and Williams, I. H. 1997. Factors influencing the structure and function of the small intestine in the weaned pig: a review. Livestock Science 51:215-236.

R Development Core Team, 2011. R: A language and environment for statistical computing. The R Foundation for Statistical Computing,
Vienna, Austria. Available at: <http://www.R-project.org/>. Accessed on: May 10, 2014.

Rostagno, H. S.; Albino, L. F. T.; Donzele, J. L.; Gomes, P. C.; Oliveira, R. F.; Lopes, D. C.; Ferreira, A. S. and Barreto, S. L. T. 2011. Tabelas brasileiras para aves e suínos: composição de alimentos e exigências nutricionais. 3.ed. Editora UFV, Viçosa, MG, Brasil.

Torrallardona, D. 2010. Spray dried animal plasma as an alternative to antibiotics in weanling pigs - A Review. Asian Australasian Journal of Animal Science 23:131-148.

Van Dijk, A.; Everts, H.; Nabuurs, M.; Margry, R. and Beynen, A. 2001. Growth performance of weanling pigs fed spray-dried animal plasma: a review. Livestock Science 68:263-274.

Yang, Y. X.; Kim, Y. G.; Lohakare, J. D.; Yun, J. H.; Lee, J. K.; Kwon, M. S.; Park, J. I.; Choi, J. Y. and Chae, B. J. 2007. Comparative efficacy of different soy protein sources on growth performance, nutrient digestibility and intestinal morphology in weaned pigs. Asian Australasian Journal of Animal Science 20:775-783.

Yi, G. F.; Carroll, J. A.; Allee, G. L.; Gaines, A. M.; Kendall, D. C.; Usry, J. L.; Toride, Y. and Izuru, S. 2005. Effect of glutamine and spray-dried plasma on growth performance, small intestinal morphology, and immune responses of Escherichia coli K88+challenged weaned pigs. Journal of Animal Science 83:634-643. 